Pace University

DigitalCommons@Pace

4-2012

\title{
Unlocking the Courthouse Door: Removing the Barrier of the PLRA's Physical Injury Requirement to Permit Meaningful Judicial Oversight of Abuses in Supermax Prisons and Isolation Units
}

Michael B. Mushlin

Elisabeth Haub School of Law at Pace University

Follow this and additional works at: https://digitalcommons.pace.edu/lawfaculty

Part of the Constitutional Law Commons, and the Criminal Law Commons

\section{Recommended Citation}

Michael B. Mushlin, Unlocking the Courthouse Door: Removing the Barrier of the PLRA's Physical Injury Requirement to Permit Meaningful Judicial Oversight of Abuses in Supermax Prisons and Isolation Units, 24 Fed. Sent'g Rep. 268 (2012), http://digitalcommons.pace.edu/lawfaculty/829/.

This Article is brought to you for free and open access by the School of Law at DigitalCommons@Pace. It has been accepted for inclusion in Pace Law Faculty Publications by an authorized administrator of DigitalCommons@Pace. For more information, please contact dheller2@law.pace.edu. 


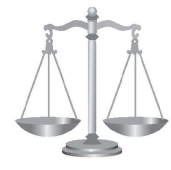

MICHAEL B. MUSHLIN*

Professor of Law, Pace Law School

\section{Unlocking the Courthouse Door: Removing the Barrier of the PLRA's Physical Injury Requirement to Permit Meaningful Judicial Oversight of Abuses in Supermax Prisons and Isolation Units}

In the winter of 200I, Tyron Alexander and Kevin Carrol were being held in a jail awaiting appearance in court when they were involved in a fight with two prison guards. Apparently no one was seriously injured, but Alexander and Carrol were placed in an isolation cell. ${ }^{\mathrm{I}}$ Aptly named "the hole," the cell, a "sparse" 64-square-foot space meant to contain only one person, held no running water and no toilet. $^{2}$ At first both Alexander and Carrol were stripped of their clothing and were naked. Later they were given boxer shorts but no other clothing to wear. Instead of a toilet the cell had a grate-covered hole in the floor that could only be flushed by prison officials outside the cell. Carroll became nauseated soon after being confined in the cell and was forced to defecate into the drain, after which he was allowed only one sheet of toilet paper for cleaning purposes. Afterwards, the drain became obstructed with feces. Alexander and Carrol tried to clear the obstruction but were not successful. No one helped them. When they had to urinate, urine splattered from the clogged drain onto the cell floor. The smell nauseated Carrol who then vomited into the drain. When the guards finally decided to do something they were unable to flush the drain. Nevertheless, rather than release Carroll and Alexander from the contaminated cell, the guards kept them confined. The guards then instructed an inmate trusty to spray water into the cell through an opening at the bottom of the cell door. But this was a failure which only served to further spread the waste across the floor. Desperate, Carroll and Alexander requested a mop to clean the mess. The request was denied, and they remained confined in the stench of the dirty, contaminated isolation cell. Because they were not let out of the cell and because it had no running water, Carroll and Alexander could not wash their hands. When it came time to eat, they were not given utensils. In this urine-, feces-, and vomitinfested cell prison officials served Carroll and Alexander lunch and dinner. There was no bed but instead a concrete protrusion from the wall with space for just one person. No mattress or sheets or blankets were provided even though the men were clothed only in boxer shorts on that winter evening. That night in the cold they tried to sleep by sharing the small concrete slab.

After they were released Alexander and Carroll sued for violations of their constitutional rights. Crediting all these facts as true for the purposes of its decision, 3 both the trial court and the Fifth Circuit Court of Appeals held that the case must be dismissed nevertheless because of the Prison Litigation Reform Act's prohibition on suits that do not involve physical injury. ${ }^{4}$

Steven Jarriett's case was dismissed by the Sixth Circuit for the same reason. 5 In 2006 Jarriett was involved in a fight with another inmate. He was sent to the prison's segregation unit where he was placed for over thirteen hours in a "strip cage," a tiny two-and-a-half-feet square enclosure with so little room that it was impossible to recline and difficult to even sit. This was excruciatingly painful for Jarriett, who had an injured leg. After his release, he, too, brought suit. However, he lost for the same reason as Alexander and Carroll: there was no physical injury involved in his suffering, and so his case was barred by the Prison Litigation Reform Act. ${ }^{6}$

A third case involving Essam Mohammed Jameel Najeed Adnan met a parallel fate. ${ }^{7}$ Mr. Adnan, for no apparent reason other than the fact that he is an Arab American, was placed in solitary confinement for more than three months where he was shackled at his arms and legs and let out of his cell for only three hours a week although he had no violent history and had been classified as a minimum security risk. These conditions had an intense effect on Mr. Adnan. Following his release, he was required to take three different anti-depressants. Prior to this episode he had no history of mental illness. When Mr. Adnan sued, the court held that he had presented a valid claim for a violation of his constitutional rights, but he was denied compensatory damages because he was not physically injured during his stay in segregation. ${ }^{8}$

What these cases have in common is that each deals with conditions in a solitary confinement or isolation or segregation unit in a modern American penal institution. What goes on in these units, which have dramatically increased in number over the last thirty years, has enormous significance and has attracted the concerned attention of national and international groups. 9 These cases also illustrate that the threat of abuse in these units is quite high. Finally, what these cases have in common is that in each the PLRA's physical injury requirement was invoked to terminate the plaintiff's claim for compensatory

Federal Sentencing Reporter, Vol. 24, No. 4, pp. 268-275, ISSN 1053-9867 electronic ISSN 1533-8363. (C) 2012 Vera Institute of Justice. All rights reserved. Please direct requests for permission to photocopy or reproduce article content through the University of California Press's Rights and Permissions website, http://www.ucpressjournals.com/reprintInfo.asp. DOI: IO.I525/fsr.20I2.24.4.268. 
damages. This is an intolerable result for a country that prides itself on its embrace of the rule of law.

This article addresses this problem and calls for changes that would remove the shackle of the PLRA's physical injury requirement, which prevents federal courts from vindicating the rights of persons who are subjected to unconstitutional treatment in isolation units in America. The article has three parts. Part I provides a brief history of the use of solitary confinement in the United States, describes the current use of solitary, and outlines the dangers to human rights that are posed by the operation of isolation and solitary confinement units. Part II describes how the physical injury requirement of the PLRA, as currently interpreted by a majority of the courts, prevents inmates from vindicating their rights. Part III is a call for repeal or reform of the physical injury requirement. It urges Congress to repeal the provision and provides reasons why it should do so. It also argues that, if the law stays on the books, the courts should interpret this provision in a manner that is more faithful to the legislative history of the PLRA, and in a manner that permits courts to offer meaningful remedies for serious conditions impacting inmates in solitary confinement units.

\section{Isolation and Solitary Confinement in the United States}

The increased use of solitary confinement-or the isolation of a prisoner from other inmates and most social contact-is one of the most pressing issues in American corrections. The use of isolation has grown dramatically in recent years. ${ }^{10}$ Currently, unprecedented numbers of inmates are being held in isolation, solitary confinement, or supermax units, as they are variously known. While the numbers are greater than ever before, solitary confinement is not a new development. Indeed, this country was the first to make solitary an institutionalized part of the normal operation of its prisons. One might even say that solitary as we know it was invented here. ${ }^{\text {II }}$ When the first modern prisons were established, with the advent of the Pennsylvania penitentiary system early in this history of this country, solitary confinement was chosen as the method best designed to lead to reformation of criminals. ${ }^{\mathrm{I2}}$ The theory was that a prisoner left alone in his cell, isolated from harmful outside influences, would become penitent through reflection upon his sins. ${ }^{13}$ However, it soon became apparent that rather than becoming rehabilitated, prisoners kept under such conditions were actually deteriorating mentally and had higher death rates than other prisoners. ${ }^{14}$ Charles Dickens, perhaps the most famous visitor to American prisons at that time, was appalled by the impact of solitary on human beings. Calling solitary "a dreadful punishment" which inflicts an "immense amount of torture and agony ... which no man has a right to inflict upon his fellow-creature," Dickens concluded, "I hold this slow and daily tampering with the mysteries of the brain, to be immeasurably worse than any torture of the body ...."15
Because of this failed experiment, solitary confinement was rarely used and fell out of disfavor in the United States. ${ }^{16}$ However, over the last thirty years, with the dramatic rise in prison populations, solitary confinement has been rediscovered. Some trace the modern use of solitary to its reinstatement at the federal prison in Marion, Illinois, following a prison riot in $1983 .{ }^{17}$ The supposed success of that use at Marion sparked others to establish their own solitary, isolation, or supermax facilities, ${ }^{18}$ and the use of solitary has grown since then. ${ }^{19}$ While the Department of Justice's Bureau of Justice Statistics does not offer statistics regarding the number of people in solitary, ${ }^{20}$ as of 2004 at least 25,000 prisoners were housed in so-called "supermax" prisons where all prisoners are kept in isolation. ${ }^{2 \mathrm{I}}$ In addition, at least another 50,000 to 80,000-perhaps more-prisoners are in segregated units in other prisons and jails. ${ }^{22}$

Conditions vary, but many isolated prisoners typically spend between twenty-two and twenty-three hours per day in cells that can be as small as six feet by eight feet. ${ }^{23}$ Prisoners typically are let out for only a few hours a week for showers and exercise, are strictly limited as to what personal items or reading material they may retain, and are often kept in windowless rooms that are in some units lit twenty-four hours a day with fluorescent lighting, making it difficult for the prisoner to even know if it is night or day. ${ }^{24}$ Even time spent out of their cells is often time spent alone, and prisoners are normally forbidden to talk to each other through their cell walls. ${ }^{25}$ Prisoners may also be prohibited from having radios, televisions, or most forms of reading materials. ${ }^{26}$ It is not surprising, therefore, that when kept under these conditions for long periods of time, prisoners may experience a number of psychological problems and mental illnesses, including self-mutilation, anxiety, panic disorder, difficulty in thinking and remembering, suicidal tendencies, depression, and impulse control problems. ${ }^{27}$ Prisoners already suffering from mental illness before being placed in solitary fare even worse. ${ }^{28}$

Providing modern scientific support to the observations of Charles Dickens regarding the torturous nature of this type of confinement, studies have demonstrated that such isolation can have ruinous effects on individuals. ${ }^{29}$ One observer, for example, reported that 50 percent of inmates who commit suicide are found within the 2 to 8 percent of those inmates housed in solitary. ${ }^{30}$

In addition, isolation units create an environment in which additional abuses can and do occur. ${ }^{3}$ One need look no further than the cases identified at the beginning of this article for evidence that isolation/solitary confinement units provide fertile soil for mistreatment and abuses of prisoners. The treatment that Alexander and Carroll received in the filthy strip cell and the suffering Jarriett experienced in his small strip cage, and the prolonged, unnecessary isolation to which Adnan was subjected are all typical examples of the kinds of abuses that occur in solitary confinement units. ${ }^{32}$ As one observer put it, "Because of the absence of witnesses, solitary confinement increases 
the risk of acts of torture or other cruel, inhuman or degrading treatment or punishment." 33

Solitary confinement, as practiced in the United States, has drawn the attention of observers both here in the United States and abroad. On the national scale, one example is the National Commission on Safety and Abuse in American Prisons, which, in a comprehensive report on conditions in American prisons, concluded that solitary confinement should only be used as "a last resort." 34 The report also recommended that prison systems be much more careful about using solitary for inmates whose conduct did not justify it, and that even for situations where solitary was needed that steps be taken to lessen the severity of the isolation by giving "prisoners in segregation opportunities to fully engage in treatment, work, study, and other productive activities, and to feel part of a community." 35 The Commission urged that prisoners with a mental illness that would make them particularly vulnerable to conditions in segregation be housed in secure therapeutic units rather than in solitary confinement. ${ }^{36}$

America's use of solitary has also caused international attention. For example, the Committee Against Torture, the official body established to monitor compliance with the International Convention Against Torture, a treaty ratified by the United States, ${ }^{37}$ expressed concern about the severe isolation in America's "supermaximum prisons." 38 In August 20II the United Nations' Special Rapporteur of the Human Rights Council, in a report to the General Assembly of the UN on torture and other cruel, inhuman, or degrading treatment or punishment, pointing to extensive use of solitary confinement in the United States found that prolonged solitary confinement, which it defined as isolation for more than I5 days, violates the International Covenant on Civil and Political Rights. 39

Despite all this concern, courts in this country have been handicapped in their ability to fully address conditions in solitary confinement units in American prisons because of numerous provisions in the Prison Litigation Reform Act. ${ }^{\circ}$ One such provision is the physical injury requirement to which we now turn.

\section{The Physical Injury Requirement}

Despite the clear and present danger of abuse presented by the extensive use of solitary confinement in the United States, the physical injury requirement of the Prison Reform Litigation Act, as currently interpreted, erects a formidable barrier for persons who seek compensation and vindication for the abuses that they have suffered in solitary. That section provides, as a limitation on recovery, that no prisoner may bring a federal civil action "for mental or emotional injury suffered while in custody without a prior showing of physical injury." $4 \mathrm{I}$ The majority of courts have chosen to construe this provision to require actual non-de minimis physical harm before they will even entertain a lawsuit for damages for abuses. ${ }^{2}$ Thus, "complaints of exposure to unconstitutional prison living conditions"those that deny the "minimal civilized measure of life necessities" - without physical injury are considered to be claims of mental or emotional injury for which compensatory damages are barred. 43

The effect of this interpretation is that shocking cases for damages for abuses in solitary confinement units are dismissed without so much as a hearing. In the soiled unsanitary strip cell in which they were confined, Alexander and Carroll suffered through a ghastly experience, but because of the physical injury provision of the PLRA the case ended. Jarriett was not just isolated for thirteen hours; he was confined in a space too small for him to even sit without "balling" himself up, much less lie down. 44 While he alleged that he had a bad leg and thus experienced severe pain, the court found no physical injury and so his claims for compensatory damages was dismissed because of the physical injury provision. 45 Finally, Adnan was held in absolute isolation and shackled without any justification, but here, too, the conditions did not cause physical injury so his claim for compensatory damages was undermined by the PLRA. ${ }^{6}$ These cases illustrate that the PLRA, with its physical injury requirement, makes the assertion of a valid claim for compensatory damages extraordinarily difficult, if not impossible. Even when an inmate can claim some physical injury, courts will often term the injury de minimis and dismiss the claim for damages. 47 Courts in these situations have allowed for injunctions in cases in which there is a need for equitable relief to enjoin further abuse. ${ }^{8}$ However, injunctions are often not available, and even when they are they do not compensate for past harm. ${ }^{49}$ The most that is available under the majority view for inmates who have been abused in solitary confinement but did not suffer physical injury, and at the time the lawsuit is brought are not seeking injunctive relief, ${ }^{\circ}$ is nominal damages and the possibility, remote though it is, of punitive damages..$^{\mathrm{I}}$

\section{A Call for Repeal or Reform of the Physical Injury Requirement}

The physical injury requirement, as interpreted by the majority of courts, is an affront to the rule of law. With it, conditions that would shock the conscience of American sensibility are insulated from judicial review and go unremedied. This would be a bad result in any setting, but in the prison field where the lack of oversight is so glaring, and the need for oversight so necessary, ${ }^{52}$ this is even more intolerable. There are two solutions to this problem. One is that Congress should repeal the physical injury requirement. The other is that federal courts should interpret the provision to allow suits to correct abuses such as those described in this article.

\section{A. Congress Should Repeal the Physical Injury Requirement}

There is nothing in the legislative history of the PLRA that justifies the physical injury requirement. As we have seen, it interdicts otherwise valid constitutional claims. But there 
is no evidence that Congress actually intended to prohibit "legitimate constitutional claims simply because the prisoner suffered no physical injury." 53 Rather, the legislative history of the act, sparse though it is, ${ }^{54}$ demonstrates clearly that what was on Congress members' minds was imposing some realistic checks on frivolous lawsuits by prisoners who had nothing but time on their hands and who used these suits as a way of distracting themselves from the tedium of prison life, 55 while draining public resources needed to defend the lawsuits ${ }^{5}$ and diverting the attention of prison administrators that could be spent on better things. These concerns were not completely baseless. In I993, a few years before the PLRA was enacted, prison cases were a little over 40 percent of the appeals filed in federal courts. 57 Prison cases had also increased dramatically in the district courts..$^{8}$ Many members of Congress believed that some of these suits, the overwhelming majority of which were filed and prosecuted pro se without the benefit of counsel, were frivolous. ${ }^{59}$ Senators took the floor in support of the PLRA decrying lawsuits that were filed in response to "almost any perceived slight or inconvenience" ${ }^{6 \circ}$ such as those involving claims over bad haircuts, inadequate locker space, and "being served 'hacked up' cake." ${ }^{6 I}$ In their zeal to weed out perceived frivolous lawsuits, however, Senators avowed that it was not their intent to discourage prisoners from bringing "legitimate" and "meritorious" claims. ${ }^{62}$ One Senator, for instance, guaranteed that the PLRA "will allow meritorious claims to be filed." ${ }_{3}$ In the words of one commentator who reviewed the legislative history of the PLRA, "Senators repeatedly claimed that the PLRA would not prevent legitimate constitutional claims from being litigated and redressed." 64 With this background it is difficult to understand what Congress had in mind when it included the physical injury component in the PLRA. Regardless, in light of the overwhelming evidence that (I) the drafters of the PLRA had no intent to close the courthouse doors to legitimate meritorious cases, and (2) the physical injury requirement of the PLRA, as currently interpreted by courts, has had just that effect, there is nothing to lose and everything to gain by repealing this provision of the PLRA.

\section{B. Courts Should Interpret the Physical Injury Provision in a Manner that Restores the Ability of Courts to Remedy Constitutional Abuses in Solitary Confinement Units}

While repeal of the physical injury provision of the PLRA is the cleanest solution, there is another method to provide judicial oversight to address abuses in solitary confinement: federal courts should construe the vague physical injury provision ${ }^{65}$ not to exclude constitutional claims for compensation for abuses in solitary confinement units. Put another way, claims for cruel and unusual punishment and procedural due process violations in solitary confinement units such as those described in this article should be regarded as constitutional claims that do not depend for their violation on a finding of physical, emotional, or mental injury and thus are not barred by the physical injury provision. Currently a majority of the courts have not followed this path. They have read the physical injury provision of the PLRA to bar any constitutional claim for compensatory damages that an inmate asserts, no matter how valid it may be, if the violation of constitutional rights did not produce a physical injury. ${ }^{66}$ This interpretation overlooks that constitutional claims by inmates who are abused in solitary confinement typically are claims which by their nature do not require physical injury as an essential element of the claim. Eighth Amendment claims for cruel and unusual punishment, for example, are based on a finding of the objective seriousness of the conditions to which an inmate is exposed. If these conditions fall below "the minimal civilized measure of life's necessities," 67 or if they fail to meet the "identifiable human need[s]" of inmates ${ }^{68}$ and if they are imposed with deliberate indifference ${ }^{6} 9$ to these objective needs, then there is a constitutional violation according to decisions of the Supreme Court, regardless of whether the conditions cause physical injury. The basic protection of the Eighth Amendment, in other words, is not against just physical injury; rather, it is protection against profound affronts to human dignity. $7^{\circ}$ One need look no further than the abuses that were inflicted on inmates at the notorious Abu Ghraib prison to appreciate that cruel and inhuman punishment can be inflicted without the necessity of proving actual physical injury. ${ }^{7 \mathrm{I}}$ The same is true for procedural due process violations that occur when inmates are subjected to indefinite confinement in solitary confinement units without meaningful review. ${ }^{72}$ The injury that is protected against here is the injury to liberty, which, of course, can occur without regard to whether there is physical injury. The majority interpretation of the PLRA thus cuts off claims for compensatory damages for violations of this fundamental constitutional right. This, in the words of one commentator, "[n]ot only . . leave[s] the prisoner without the ability to invoke the judicial power to protect his fundamental rights, but it also sends a powerful message to prison authorities that they may engage in constitutional wrongdoing without fear of judicial penalty."73

A few courts have rejected this narrow approach, holding that the PLRA was not meant to bar constitutional claims. A good example is Robinson v. Page,74 in which Judge Richard Posner held that an Eighth Amendment claim for exposure to asbestos unaccompanied by a claim of physical injury is not barred by the PLRA. Judge Posner observed that "[i]t would be a serious mistake to interpret section I997e(e) to require a showing of physical injury in all prisoner civil rights suits." 75 This interpretation is more in accord with the legislative history of the PLRA, ${ }^{76}$ more in line with tort doctrine, 77 and more respectful of the essential role of the federal courts in our constitutional system of governance. ${ }^{78}$ It should be adopted by the courts.

\section{Conclusion}

The physical injury provision of the Prison Litigation Reform Act, as interpreted by the majority of the courts, 
creates a barrier between the Constitution and solitary confinement and isolation units in American prisons. This is inconsistent with the rule of law and the admonition of the Supreme Court that there "is no iron curtain drawn between the Constitution and the prisons of this country."79 It, therefore, should be abolished either through legislation or through judicial interpretation.

\section{Notes}

* I express my deep appreciation to Adonia David, Pace Law School Class of 2012, for her superb assistance in the preparation of this article.

1 Alexander v. Tippah Cnty., Miss., 351 F.3d 626 (5th Cir. 2003).

2 Id. at 628. The facts recounted about the case are drawn from this opinion.

3 Id. at 630-31.

4 Id. at 631 (citing 42 U.S.C. $\S 1997 \mathrm{e}(\mathrm{e})$ (2006)).

5 Jarriett v. Wilson, 162 F. App'x 394 (6th Cir. 2005). The facts recounted about the case are drawn from this opinion.

6 Id. at 401.

7 Adnan v. Santa Clara Cnty. Dep't of Corr., No. 4:02-CV-03451, C 02-3451 CW (PR), 2002 WL 32058464, at*2 (N.D. Cal. Aug. 15, 2002). The facts recounted about the case are drawn from this opinion.

8 Id. at *3.

9 See Comm'n on Safety \& Abuse in America's Prisons, Confront. ING Confinement 52-61 (2006); ABA StANdARds FOR CRIMINAL Justice: Treatment of Prisoners (2010); U.N. Comm. Against Torture, Consideration of Reports Submitted by States Parties Under Article 19 of the Convention: Conclusions and Recommendations of the Committee Against Torture: United States of America, 36th Session, May 1-19, 2006, U.N. Doc. CAT/C/USA/CO/2, at $\uparrow 36$ (July 25, 2006) [hereinafter U.N. Comm. Against Torture: Conclusions and Recommendations], available at http://www.unhcr.org/refworld/

publisher,CAT,,USA,453776c60,0.html; Special Rapporteur of the Human Rights Council, Interim Report on Torture and Other Cruel, Inhuman or Degrading Treatment or Punishment, U.N. Doc. A/66/268 (Aug. 5, 2011) (by Juan E. Méndez).

10 Between 1995 and 2000 the growth rate for the number of prisoners in segregation was 40 percent as opposed to a 28 percent growth rate for the number of prisoners in the overall prison population. COMm'n ON SAFETY \& ABUSE IN AMERICA'S Prisons, supra note 9, at 53.

11 See, e.g., Michael B. Mushlin, Rights of Prisoners $\S 1.2$ (4th ed. 2011) (describing the history of the American prison sys. tem and its early prisons "marked by isolation [and] silence").

12 Stuart Grassian, Psychiatric Effects of Solitary Confinement, 22 WASH. J.L. \& POL'Y 325, 328 (2006).

13 See Bruce A. Arrigo \& Jennifer Leslie Bullock, The Psychological Effects of Solitary Confinement on Prisoners in Supermax Units: Reviewing What We Know and Recommending What Should Change, 52 Int'L J. Offender Therapy \& Comp. Criminology 622, 623 (2008); Elizabeth Vasiliades, Solitary Confinement and International Human Rights: Why the U.S. Prison System Fails Global Standards, 21 Am. U. INT'L L. REv. 71, 73 (2005).

14 Tracy Hresko, In the Cellars of the Hollow Men: Use of Solitary Confinement in U.S. Prisons and Its Implications under International Laws Against Torture, 18 PACE INT'L L. Rev. 1, 6 (2006).

15 Charles Dickens, American Notes 146 (Fromm Int'l 1985) (1842), cited in Jules Lobel, Prolonged Solitary Confinement and the Constitution, 11 U. PA. J. Const. L. 115, 118 (2008). See also In Re Medley, 134 U.S. 160, 168 (1890) ("A considerable number of the prisoners fell, after even a short confinement, into a semi-fatuous condition, from which it was next to impos. sible to arouse them, and others became violently insane; others still, committed suicide; while those who stood the ordeal better were not generally reformed, and in most cases did not recover sufficient mental activity to be of any subsequent service to the community."); Davenport v. DeRobertis, 844 F.2d 1310, 1316 (7th Cir. 1988), cert. denied, 488 U.S. 908 (1988) (noting the wealth of literature concerning the det rimental effects of solitary confinement); Madrid v. Gomez, 889 F. Supp. 1146, 1230-31 (N.D. Cal. 1995) (noting clinical and scientific findings that human beings subjected to isola. tion may "deteriorate mentally and in some cases develop psychiatric disturbances.").

16 Hresko, supra note 14 , at 7.

17 Id.

18 After the establishment of the isolation facility in Marion, other states followed suit, with between thirty and thirty-four constructing similar facilities by 1999. Lena Kurki \& Norval Morris, The Purposes, Practices and Problems of Supermax Prisons, in 28 Crime and Justice, A Review of Research 385, 385 (Michael Tonry ed., 2001), available at https://www. ncjrs.gov/pdffiles1/Digitization/192542-192549NCJRS.pdf; see also Daniel P. Mears \& Michael D. Reisig, The Theory and Practice of Supermax Prisons, 8 PUNISHMENT \& Soc'y 33, 33 (2005), available at http://pun.sagepub.com/content/8/1/33. full.pdf+html.

19 Hresko, supra note 14, at 7-8.

20 N.Y.C. Bar Ass'n COMm. on InT'L Human Rights, The Brutality of SuPERMAX CONFINEMENT 9 (2011).

21 Arrigo \& Bullock, supra note 13, at 624. Supermax prisons have been defined by the National Institute of Corrections as restrictive housing units where violent or escape-prone pris. oners, or those who might instigate disturbances, are isolated from each other as well as the general prison popula tion. However, this definition can hide the fact that assignment to supermax prisons is generally long-term with prison officials wielding great discretion over what may be considered a sufficient security risk, and that often supermax facilities include almost total isolation with prisoners spending approximately twenty-three hours a day in windowless cells. Some facilities limit any personal interaction even between inmates and staff. Kurki \& Morris, supra note 18 , at 388-90; see also Craig Haney, Mental Health Issues in LongTerm Solitary and "Supermax" Confinement, 49 CRIME \& Delinguency 124, 125-127 (2003).

22 Atul Gawande, Hellhole, New Yorker, Mar. 30, 2009, at 36, available at http://www.newyorker.com/reporting/2009/ 03/30/090330fa_fact_gawande. Support for the use of supermax prisons focuses on the idea that isolating the most dangerous inmates from the general prison population will contribute to prison security, protect other inmates and prison staff, and deter other prisoners from misconduct. However, arguments exist, based on general deterrent research, that housing prisoners in supermax prisons may not even fulfill the supposed function of maximizing prison security. The threat of placement in a supermax facility may offer little deterrence to prisoners as such decisions are often administrative and based on reasons over which prisoners have little control. It is possible that supermax prisons actually contribute to less prison security because those released from supermax into the general prison population may be so filled with rage that they are more prone to violence towards other inmates and prison staff. See, e.g., Jesenia Pizzaro \& Vanja M.K. Stenius, Supermax Prisons: Their Rise, Current Practices, and Effects on Inmates, 84 PRISON J. 248, 261 (2004); see also Jeffrey Smith McLoeod, Anxiety, Despair, and the Maddening Isolation of Solitary Confinement: Invoking the First Amendment's Protection Against State Action That Invades the Sphere of the Intellect and Spirit, 70 U. PITT. L. REV. 647, 657 (2009) (noting that solitary can contribute to low impulse control in prisoners and keeping prisoners in solitary 
can actually lessen community safety when they are released.).

23 Arrigo \& Bullock, supra note 13 , at 624.

24 ld. at 625.

25 Hresko, supra note 14 , at 8

26 Id. at 9 . These kinds of restrictions were upheld by the United States Supreme Court in Beard v. Banks, 548 U.S. 521 (2006). An indication of the impact this kind of treatment can have is that in at least one case, when a prisoner was finally given a television, he began to hear voices emanating from it that he thought were speaking directly to him. Gawa. nde, supra note 22.

27 Arrigo \& Bullock, supra note 13, at 628.

28 See Madrid v. Gomez, 889 F. Supp. 1146, 1216 (N.D. Cal. 1995) (noting expert testimony that inmates with existing mental health issues "are at a higher risk of deteriorating in the SHU.”). See generally Grassian, supra note 12 (indicating that general medical literature points to the fact that individu. als with underlying mental vulnerabilities fare worse in isolating situations than those with healthy mental functioning; among other studies and observations, the article relates a story of female prisoners with histories of mental illness who were placed in isolation, resulting in a nightmarish situa. tion where "many became grossly disorganized and psychotic, smearing themselves with feces, mumbling and screaming incoherently all day and night, some even descending to the horror of eating parts of their own bodies.").

29 Hresko, supra note 14 , at 11 . Observation of the impact of isolation on individuals comes from a variety of sources: for example, the experience of prisoners of war and hostages. Studies regarding the effects of isolation on baby monkeys showed that they were unable to function when placed with normal monkeys and that "twelve months of isolation almost obliterated the animals socially." These studies were seen to be so cruel that they helped to start the animal rights move. ment. Gawande, supra note 22.

While most studies support the contention that solitary confinement is detrimental to inmates' mental and physical health, there does appear to be a correlation between the length and conditions of confinement and the detrimental effects and it has not yet been proven that short-term solitary confinement has the same severe consequences as long-term confinement. Arrigo \& Bullock, supra note 13 , at 627. In addition, there are a few studies that have contradicted the findings that individuals in solitary suffer severe consequences.

Two studies have found that limited solitary confinement did contribute to better inmate behavior and, surprisingly, to better inmate outlook and optimism. See P. Suedfeld \& C. Roy, Using Social Isolation to Change the Behavior of Disruptive Inmates, 19 J. offender Therapy \& Comp. CRIMInology 90 (1975); P. Suedfeld, Reactions and Attributes of Prisoners in Solitary Confinement, 9 CRIM. J. \& BeHAV. 303 (1982). However, it is important to note that one of these studies involved only four inmates who were in solitary for no more than thirty days, and the other involved only prisoners who had volunteered to take part in the study in simulated isolation units. Such conditions are not indicative of outcomes in real-life situations, given that prisoners in solitary do not volunteer for the isolation and are often there for much longer than thirty days. Pizzaro \& Stenius, supra note 22 , at 257 . There is also a recent study that focused on Colorado inmates in administra. tive segregation and purported to bring an empirical analysis to the issue through a systematic study of the effects of solitary on prisoners, both with and without previous mental illnesses, as well as comparison with a control group of pris. oners in the general population. MAUREEN L. O'KeEFE ET AL., ONE Year Longitudinal Study of the Psychological Effects of Admin. ISTRATIVE Segregation, at ii (2010). Among other results, this study found that mentally ill prisoners in administrative segre. gation did not deteriorate at a rate greater than non-mentally ill prisoners, and that while those prisoners in segregation did have higher psychological markers than "normative adult samples," this was true for the control group in the general prison population as well. Id. The study also found an initial improvement in all prisoners' psychological well-being during the first interval of testing. Id. at viii.

There has been criticism of the Colorado study, including that it ignored suicide crisis amongst prisoners that took place during the study's analysis, and that it only accepted those prisoners who could read and write at an eighth-grade level. Stuart Grassian \& Terry Kupers, The Colorado Study v. The Reality of Supermax, 13 Corr. Mental Health Rep. 1, 9 (2011). Illiteracy is one of the factors correlated with psychiatric deterioration in solitary. Furthermore, the fact that only those prisoners willing to volunteer for the study were looked at means that those prisoners excluded may have been those more likely to suffer detrimental effects. In addition, the Colo. rado study may not be indicative of the conditions in other solitary units; the facility in Colorado had windows in the walls where inmates could see outside. There were also win. dows in the doors through which they could see each other and use sign language to communicate, and the inmates also had access to educational programs, televisions, and radios, as well as reading material, art materials, and games. Jamie Fellner, What Should We Think About the Study on the Psychological Impact of Confinement at Colorado State Penitentiary? A Human Rights Perspective, 13 Corr. Mental Health Rep. 5, 5 (2011). While studies of inmates involuntarily housed in solitary also suffer from limitations such as the failure to look at inmates' mental health prior to their time in solitary, the majority of research does point to the fact that solitary confinement has a harmful effect on prisoners. Pizzaro \& Stenius, supra note 22, at 257. These studies are supported by research and observations on the effects of isolation. See generally Grassian, supra note 12, at 344-45 (mentioning the effects of solitary on prisoners of war and studies concerning the effects of sensory deprivation); Gawande, supra note 22 (discussing the effects of isolation on prisoners of war and hostages, and detrimental effects of isolation on individuals, other than inmates, who have been held in similar situations).

30 Grassian \& Kupers, supra note 29, at 9.

31 See e.g., Kurki \& Morris, supra note 18, at 409; Special Rap. porteur of the Human Rights Council, supra note 9 , at 19 ("Because of the absence of witnesses, solitary confinement increases the risk of facts of torture and other cruel, inhuman or degrading treatment or punishment."); COMM'N ON SAFETY \& ABUSE IN AMERICA's PRISONS, supra note 9, at 14 ("There is troubling evidence that the distress of living and working in this environment actually causes violence between staff and prisoner.").

32 See Alexander v. Tippah Cnty., Miss., 351 F.3d 626 (5th Cir. 2003); Jarriett v. Wilson, 162 F. App'x 394 (6th Cir. 2005); Adnan v. Santa Clara Cnty. Dep't of Corr., No. 4:02-CV-03451, C 02-3451 CW (PR), 2002 WL 32058464, at *2 (N.D. Cal. Aug. 15, 2002).

33 Special Rapporteur of the Human Rights Council, supra note 9 , at 19.

34 Comm'n on Safety \& Abuse in America's Prisons, supra note 9 , at 53.

35 Id. at 56

36 Id. at 59. The American Bar Association, after a five-year drafting process, in 2010 approved a set of minimum stan. dards that also called for significant changes. Among these are appropriate procedures prior to placing a prisoner in solitary, limiting the duration of solitary, decreasing extreme isolation, close mental health monitoring for people 
in solitary, and ending the solitary confinement of the mentally ill. ABA STANDARDS, supra note 9. The relevant standards are Standard 23.2.5 through Standard 23-2.9 and Standard 23-3.8. Full text of the Standards is available at http:// www.americanbar.org/publications/criminal_justice_sec. tion_archive/crimjust_standards_treatmentprisoners.html.

37 U.N. Convention Against Torture and Other Cruel, Inhuman or Degrading Treatment or Punishment, Dec. 10, 1984, 1465 U.N.T.S. 85. The United States ratified the treaty on October 21, 1994. United Nations Treaty Collection, Status of the Convention Against Torture, available at http://treaties. un.org/Pages/ViewDetails.aspx?src=TREATY\&mtdsg_no=IV. 9\&chapter=4\&lang=en.

38 U.N. Comm. Against Torture: Conclusions and Recommendations, supra note 9 .

39 Special Rapporteur of the Human Rights Council, supra note 9, at 23. The Rapporteur, observing that even short-term solitary confinement can amount to torture, id. at 20, concluded that because of its torturous nature, "[t]he use of solitary confinement can be accepted only in exceptional circum. stances where its duration must be as short as possible and for a definite term that is properly announced and communi cated," id. at 23. Terms of more than fifteen days should be prohibited. The report also warned of the danger of abuses of prisoners above and beyond those inherent in isolation that occur when solitary confinement units are instituted. Id. at 19 ("Because of the absence of witnesses, solitary confinement increases the risk of facts of torture and other cruel, inhuman or degrading treatment or punishment.").

40 In addition to the physical injury requirement, other provisions of the PLRA—including the exhaustion requirement, the "three strikes" requirement, and limitations on attorney fees, to name just a few-have had a dramatic impact on access to courts for inmates. For a discussion of these provisions see, for example, John Boston, The Prison Litigation Reform Act: The New Face Of Court Stripping, 67 BRook L. Rev. 429 (2001). 4142 U.S.C. 1997e(e) (2006) (emphasis added).

42 See, e.g., Turner v. Tezac, No. CIV.NO. 02-145-KAJ, 2005 WL 41563 (D. Del. Jan. 4, 2005) (holding that prisoner placed in SHU for fourteen days may not claim damages when he asserted only emotional injury; further, his time in SHU did not rise to the level of atypical hardship and so he may not even claim for nominal damages); Torres v. Logan, No. 10 Civ. 6951(PAC)(JLC), 2011 WL 1811003 (S.D.N.Y. May 11, 2011) (holding that prisoner's claim for compensatory damages for time spent in Central Punitive Segregation Unit that left him depressed and in need of mental health treatment failed when he did not claim physical injury); Harden-Bey v. Rutter, 524 F3d 789 (6th Cir. 2008) (even though inmate's indefinite confinement in administrative segregation for three years and running constitutes an "atypical and significant hardship," the inmate's claims for emotional and mental injuries suffered as a result of his isolation were dismissed because he failed to show the physical injury required by the PLRA). See also MusHLIN, supra note $11, \S 17.27$ (collecting cases).

43 John Boston \& Daniel E. Manville, Prisoners' Self.Help LitigaTION MANUAL 622 (2011) (collecting cases).

44 Jarriett v. Wilson, 162 F. App'x 394, 397 n.1 (6th Cir. 2005).

45 Id. at 397, 401.

46 Adnan v. Santa Clara Cnty. Dep't of Corr., No. 4:02-CV-03451, C 02-3451 CW (PR), 2002 WL 32058464, at*3 (N.D. Cal. Aug. 15, 2002).

47 See Pearson v. Welborn, 471 F.3d 732 (7th Cir. 2004) (inmate denied compensatory damages on his claim that he gained fifty pounds and suffered depression as a result of his place. ment in disciplinary segregation; court held that any physical injury was de minimis); Jarriett v. Wilson, 162 F. App'x 394 (6th Cir. 2005) (holding that inmate placed in prison's segregation unit "strip cage," where he was forced to stand for more than thirteen hours, did not suffer more than a de minimis physical injury, despite fact he suffered from pain and severe swelling in his leg that had been previously injured in a motorcycle accident).

48 Despite the prohibition on compensatory claims for purely mental or emotional injury, courts have generally held that the PLRA allows for injunctive relief even when no physical injury exists, including such relief for mentally ill inmates who are placed in solitary. See Royal v. Kautzky, 375 F.3d 720, 723 (8th Cir. 2004); Thompson v. Carter, 284 F.3d 411, 418 (2nd Cir. 2002); Davis v. District of Columbia, 158 F.3d 1342, 1346 (D.C. Cir. 1998) (agreeing with the District, and the United States as intervenor, that the PLRA allows claims for injunctive and declaratory relief for emotional injury). See also Jones'El v. Berge, 164 F.2d 1096, 1123-24 (W.D. Wis. 2001) (ordering injunctive relief in the transfer of some men. tally ill prisoners from supermax, and the mental health evaluation of certain others). In addition, some courts have gone so far as to allow claims for nominal or punitive damages in cases of mental anguish. Lobel, supra note 15, at 133-34.

49 Allison Cohn, Can $\$ 1$ Buy Constitutionality?: The Effect of Nominal and Punitive Damages on the Prison Litigation Reform Act's Physical Injury Requirement, 8 U. PA. J. CONST. L. 299, 324 (2006) (noting that the "availability of punitive or nominal damages ... seems to be more of an exercise in dicta than reality.").

50 See Zehner v. Trigg, 133 F.3d 459 (7th Cir. 1997); see also MusHLIN, supra note $11, \S 7.26$.

51 See Williams v. Hobbs, Nos. 10-2465, 10-2712, 2011 WL 6004086, at*10-11, *13 (8th Cir. Dec. 2, 2011) (reversing an award of $\$ 1$ in nominal damages for each day of the almost ten years prisoner was in solitary and instead order. ing that damages be no more than $\$ 1$ for every sixty days in isolation); Searles v. Van Bebber, 251 F.3d 869 (10th Cir. 2001) (stating that "as a general rule, punitive damages may be recovered for constitutional violations" and noting the court's belief that Congress did not intend to restrict punitive damages; court also noted that the government itself has taken the position that punitive damages may be available as long as they are based purely on constitutional violations, rather than mental injury).

52 See, e.g., Michele Deitch \& Michael B. Mushlin, Corrections: "Let the Sunshine In": The ABA and Prison Oversight, STATE OF Criminal Justice 2011, at 243 (Am. Bar Ass'n, Crim. J. Sect., 2011).

53 Royal v. Kautzky, 375 F.3d 720, 730 (2004) (Heaney, J., dis senting) (looking at the legislative history of 42 U.S.C. $1997 \mathrm{e}(\mathrm{e})$ in view of a circuit split on whether the provision applied to First Amendment claims and finding that little leg. islative history exists as to this section of the Act).

54 The PLRA received very little congressional attention before being passed, buried in an appropriations bill. As Senator Kennedy observed, the PLRA "was never the subject of a committee mark-up, and there is no Judiciary Committee report explaining the proposal. The PLRA was the subject of a single hearing in the Judiciary Committee, hardly the type of thorough review that a measure of this scope deserves." While some senators did voice strong objections regarding the PLRA's effect on judges' abilities to correct constitutional violations, the main concerns raised in the hearing and debate seemed to be centered its effect on courts' abilities to "issue relief in prison conditions cases" and consent decrees. See 142 Cong. REC. S2296-2300 (daily ed. Mar. 19, 1996) (statement of Sen. Kennedy \& Sen. Simon).

55 Cohn, supra note 49, at 304, n. 29; 141 CONG. REC. S14, 418 (daily ed. Sept. 27, 1995) (statement of Sen. Kyl) ("Today's system seems to encourage prisoners to file with impunity. 
After all, it's free. And a courtroom is certainly a more hospitable place to spend an afternoon than a prison cell.")

57 Cohn, supra note 49, at 304 (citing 141 Cong. REC. S14, 41718 (daily ed. Sept. 27, 1995)); see, e.g., Letter from Nat'l Ass'n of Attorneys Gen. to Senator Bob Dole (Sept. 19, 1995), reprinted in 141 Cong. REC. S14, 417-18 (daily ed. Sept. 27, 1995) ("[T]he issue of frivolous inmate litigation has been a major priority of this Association. . . . [W] estimate that inmate civil rights suits cost states at least $\$ 81.3$ million per year. Experience... suggests that, while all of these cases are not frivolous, more than 95 percent of inmate civil rights suits are dismissed without the inmate receiving anything.").

58 See Gigette M. Bejin, The 1995 Legislation for Prisoner Litigation Reform: Has the Pendulum Swung the Other Way?, $74 \mathrm{U}$. Det. Mercy L. Rev. 557, 558 (1997) (citing a study by the Fed. eral Judiciary Center); Seth F. Kreimer, Exploring the Dark Matter of Judicial Review: A Constitutional Census of the 1990s, 5 WM. \& MARY BILL RTS. J. 427, 485 (1997) (reporting that "[b]etween 1894 and 1994, prisoner civil rights cases and habeas petitions increased from one-tenth to almost one. fifth of the federal civil [trial court] docket").

59 Civil rights claims filed in district courts by state and federal prisoners rose from 25,992 in 1990 to 41,215 in 1996. Tracey Kyckelhahn \& Thomas H. Cohen, Bureau of Justice Statistics, Special Report, CiVIL Rights COMplaints IN U.S. District CourTs, 1990-2006, at 8 (2008), available at http://bjs.ojp. usdoj.gov/content/pub/pdf/crcusdc06.pdf.

60 See 141 Cong Rec. S14,611 (daily ed. Sept. 29, 1995).

61 Cohn, supra note 49, at 304 n.29 (citing 141 Cong. REC. S14, 418 (daily ed. Sept. 27, 1995) (statement of Sen. Kyl)).

62 Royal v. Kautzky, 375 F.3d 720, 730 (8th Cir. 2004) (Heaney, J., dissenting) (looking at the legislative history of 42 U.S.C. $1997 \mathrm{e}(\mathrm{e})$ in view of a circuit split on whether the provision applied to First Amendment claims and finding that little leg. islative history exists as to this section of the Act). But see Jon O. Newman, Pro Se Litigation: Looking for Needles in Haystacks, 62 BRook. L. Rev. 519, 520-22 (1996) (arguing that the cases were not as frivolous as advertised).

63 Jennifer Winslow, The Prison Litigation Reform Act's Physical Injury Requirement Bars Meritorious Lawsuits: Was it Meant To?, 49 UCLA L. REV. 1655, 1667 n.57 (2002).
64 Anh Nguyen, The Fight for Creamy Peanut Butter: Why Examining Congressional Intent May Rectify the Problems of the Prison Litigation Reform Act, 36 Sw. U. L. REv. 145, 158 n.126 (2007) (citing 141 CONG. REC. 26,449 (1995) (statement of Senator Thurmond)). See also 141 Cong. REC. 26,449 (1995) (statement of Senator Reid) ("[Prisoners who] have a merito. rious lawsuit, of course, ... should be able to file.").

65 Cohn, supra note 49, at 305. See also Nguyen, supra note 63, at 158 n.127 (citing 141 Cong. REC. 26,449 (statement of Senator Abraham) (Abraham, a proponent of the PLRA, stated that "this legislation will help protect convicted criminals' constitutional rights . . ."), and Royal v. Kautzky, 375 F. 3d 720, 729 (8th Cir. 2004) (Heaney, J., dissenting) ("There is nothing in the legislative history of $\S 1997 \mathrm{e}(\mathrm{e})$. . . to sug. gest that Congress's intent was to prevent legitimate constitutional claims simply because the prisoner suffered no physical injury.")).

66 Boston, supra note 41, at 435 ("The PLRA's mental or emo. tional injury provision may present the highest concentration of poor drafting in the smallest number of words in the entire United States Code.").

67 Cohn, supra note 49, at 307-08 n.50 (citing cases).

68 Rhodes v. Champman, 452 U.S. 337, 347 (1981).

69 Wilson v. Seiter, 501 U.S. 294, 304 (1991).

70 Estelle v. Gamble, 429 U.S. 97, 104 (1976).

71 Brown v. Plata, 131 S. Ct. 1910, 1928 (2011).

72 Darryl M. James, Reforming Prison Litigation Reform: Reclaiming Equal Access to Justice for Incarcerated Persons in America, 12 Loy. J. PuB. INT. L. 465, 468 (2011).

73 Williams v. Hobbs, Nos. 10-2465, 10-2712, 2011 WL 6004086, at *10-11, *13 (8th Cir. Dec. 2, 2011).

74 Cohn, supra note 49 , at 311 .

75170 F.3d 747 (7th Cir. 1999).

76 Id. at 748 .

77 See Winslow, supra note 62; Nguyen, supra note 63; Cohn, supra note 49 , at 305.

78 Boston \& MANVILle, supra note 43, at 624.

79 See Developments in the Law: The Impact of the Prison Litigation Reform Act on Correctional Mental Health Litigation, 121 HARV. L. Rev. 1145, 1152 (2008).

80 Wolff v. McDonnell, 418 U.S. 539, 555-56 (1974). 